DOI 10.37882/2223-2982.2021.05-2.04

\title{
ДЕЯТЕЛЬНОСТЬ ТОРГОВЫХ ПРЕДСТАВИТЕЛЬСТВ ШАХА СЕФИ I В РОССИИ: НА ПРИМЕРЕ КУПЧИНЫ ХВАДЖИ РАХМАТА ${ }^{1}$
}

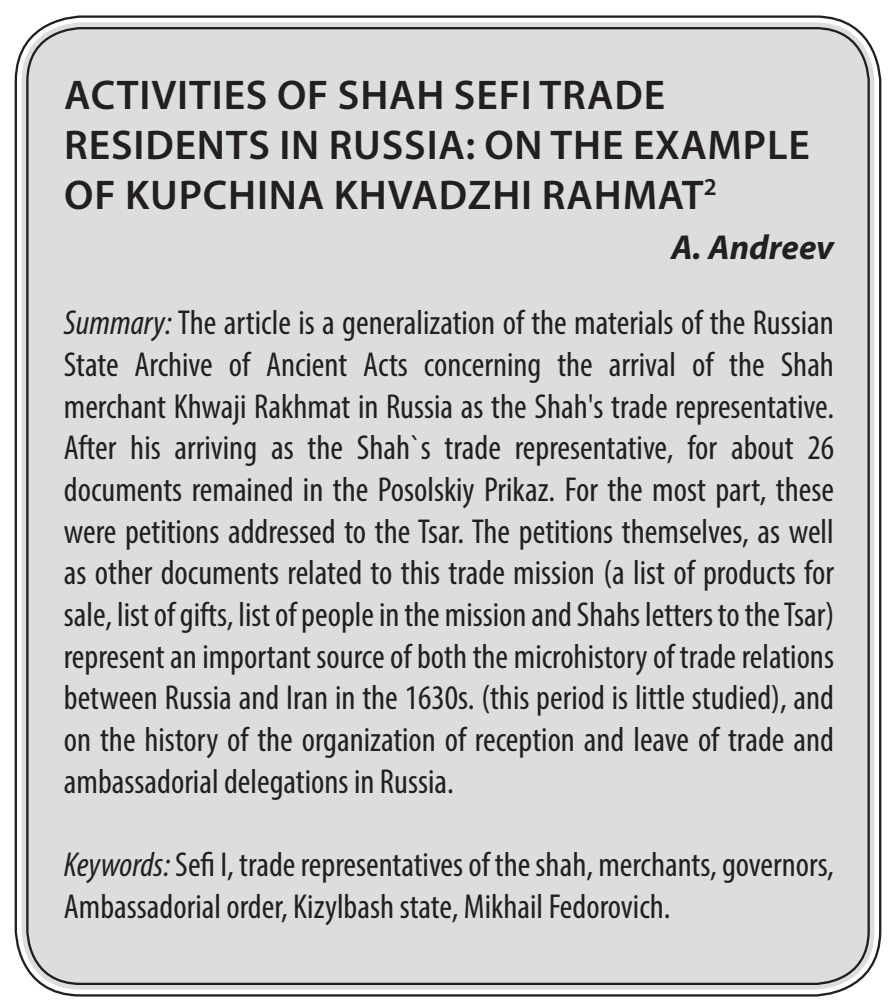

$\mathrm{H}$ езадолго до смерти шаха Аббаса I (1588-1629) российско-иранские отношения были ограничены в основном торговыми связями. Редкие политические события, наподобие авантюры Шахин-Гирея [36], имели место, но в целом, большая дипломатическая игра конца XVI - начала XVII вв. с участием Священной Римской и Османской империй отошла в прошлое. В новых условиях внешнеполитической конъюнктуры преемник Аббаса I, его внук Сефи I (1629-1642) стремился сохранить полученные им в наследство контакты с потенциально дружественными странами [33, р. 80]. Он писал астраханским воеводам: «... буди вам ведомо с великим государем з дедом моим с вашим высокостепенным государем подобно солнцу сиящему российского государства с повелителем полная была прямая дружба и любовь и соединение и всегда меж их послы и купчины

\author{
Андреев Артем Алексеевич \\ К.и.н., доцент, Санкт-Петербургский \\ государственный университет \\ a.a.andreev@spbu.ru
}

Аннотация: Статья представляет собой обобщение материалов РГАДА, касающихся приезда в Россию шахского купчины Хваджи Рахмата в качестве шахского торгового представителя. После него в Посольском приказе осталось примерно 26 документов (челобитные на имя царя Михаила Федоровича, грамоты, росписи товарам, «поминкам», людям), которые представляют собой важный источник как по микроистории торговых отношений России и Ирана в 1630-е гг. (самый малоизученный период в истории российско-иранских контактов), так и по истории организации приема и отпуска торговых и посольских делегаций в России.

Ключевые слова: Сефи I, торговые представители шаха, купчины, воеводы, Посольский приказ, Кизылбашская держава, Михаил Федорович. о добрых делах з благосчасными грамотами ходили без урыву и послан был от деда моего купчина чесной имя ж ево Хожа Рахмет Мулло» [15, л. 26-29].

Исходя из изученных материалов РГАДА, касающихся приезда купчин, послов и гонцов от Сефи I, шах в российском царстве видел преимущественно торгового партнера. Серию визитов торговых представительств иранских купчин в этот период открыл Хваджи Рахмат. В Россию его снаряжали еще при Aббасе I, но тот умер, когда купчина еще не успел покинуть пределы Ирана. Преемник не стал отменять отправку посольства, поэтому у Рахмата были грамоты (фирманы) и от Аббаса I, и от Сефи I [15, л. 26-29, 126; 16, л. 177-180]. Пребывание торгового представительства Рахмата отраженно в двух делах фонда № 77 РГАДА «Сношения России с Персией». Со-

Исследование выполнено за счет средств проекта РНФ № 18-78-10052 «Документальная история русского направления дипломатии Сефевидов (1501-1722 гг.)».

2 The study was supported by the research grant No. 18-78-10052 «The Documentary History of the Russian Strand of Safavid Diplomacy (1501-1722)» of the Russian Science Foundation. 
ставленных им или его людьми, доставленных им лично документов (включая шахские фирманы) и переводов к ним в обоих делах насчитывается порядка двадцати шести. Из них четырнадцать на персидском языке, остальные даны в русских переводах толмачей Посольского приказа. Всю документацию можно условно разделить на три группы. Первую группу составляют шахские фирманы, вторую - отчетные документы, росписи товарам и людям, третью - челобитные на имя государя Михаила Федоровича. Приезд Рахмата в Россию был подробно исследован в статьях О.М. Ястребовой и С.Е. Костикова [7; 29; 37]. В статье мы попытаемся обобщить полученные ими сведения с изученными позднее дополнительными материалами РГАДА по этому торговому представительству. В работах указанных выше авторов акцент делался преимущественно на частном содержании персидских документов Рахмата, а также на особенностях его лексики. В текстах челобитных часто встречаются экзотизмы, когда русские слова «князь», «мужик», «подводы», «подьячий» транскрибируются в арабской графике.

Российско-иранские дипломатические и торговые контакты периода 1629-1642 гг. практически не изучены. За исключением указанных выше работ имя Рахмата нигде не упоминается. На «белые пятна» истории дипломатии Сефи I, ее русского направления указывалось в работе И.К. Павловой. Объясняя данный факт, она констатировала, что «базовые источники» - труды придворных историографов того времени повествуют о событиях правления Исмаила I, Тахмаспа I и Аббаса I гораздо обстоятельнее, чем о пребывании у власти других шахов $[11$, с. 3]. С нашей стороны мы можем обозначить две причины отсутствия интереса к русскому направлению внешней политики Сефи I, равно как и иранскому направлению внешней политики царя Михаила Федоровича. Во-первых, Аббас I, успешно завершивший череду своих военных триумфов захватом Ормуза у португальцев (1622 г.) и Багдада у османов (1623 г.), уже не нуждался в новых союзниках. Да и ослабленное Смутным временем Российское царство не представляло собой надежного партнера, кроме того, интересы у обеих стран на Северном Кавказе были диаметрально противоположными. Во-вторых, по общепринятому мнению, Сефи I открывал эпоху упадка державы Сефевидов, который в полной мере проявился в начале XVIII в. [31, 32, 35].

Для российской историографии в большей степени характерен интерес к масштабным внешнеполитическим событиям, связанным с великими правителями: Аббасом I и Петром І. Период 1630-1690 гг. представляет собой настоящую лакуну в историографии, которая лишь фрагментарно восполняется немногочисленными специальными исследованиями. Например, М.С. Иванов и И.П. Петрушевский описывали события, связанные с восстанием против Сефи I в Гиляне, но при этом самому шаху там практически не уделяется внимание [4; 12]. Есть очень краткие сведения о том, как кахетинский правитель Теймураз и его сын Давид в 1639 г. дали формальную присягу в подданстве Михаилу Федоровичу в исторических записках С.М. Броневского [2, с. 55].

А.П. Новосельцев также не выделяет время правления Сефи I, но в одной из своих статей упоминает грамоту этого шаха о розыске беглых и возвращении их в Иран, датируемую 1636 г. [10, с. 105]. Н.Г. Куканова в исследовании, посвященном развитию торговли России и Ирана, вкратце упоминает о приезде купчины Ага Асана с известием о смерти Аббаса I и вступлении на престол его внука Сефи I (в ссылке при этом нет указания номера описи и номера листа дела) [14, л.92-92 об.]. Отмечены также приезды гонца Али-бека с шахской грамотой (оригинала грамоты в деле не содержится, но есть ее перевод) [17, л. 177-180]) и посла Асан-бека в сопровождении купца Ага-Магмета [8, с. 31]. В работе также сообщается о возвращении (либо приезде) тезки Асан-бека в 1641 г. с «поминками» для государя [8, с. 48]. Завершая разговор об отечественных исследованиях, можно также выделить статью Т.К. Кораева, в которой фрагментарно очерчено иранское направление русской дипломатии в 1630-е гг. и освещается попытка Гольштейна (Гольштинии) добиться для себя торговых привилегий и участия в российско-иранской торговле [6, с. 185].

Итак, как уже было указано выше, Рахмат имел статус купчины. В грамотах на языке оригинала должность называлась «киракйарак» [7, с. 123], что означало поставщика ко двору шаха или хана [30, S. 593]. Поскольку действовали ранее достигнутые договоренности между Михаилом Федоровичем и Аббасом I, которых придерживался и Сефи I, купчина освобождался от торговых сборов [3, с. 97]. В тексте перевода фирмана шаха Сефи I астраханским воеводам есть краткое упоминание о том, что сам Рахмат родом из Багдада. У него к моменту его приезда уже был опыт пребывания в России. В первый раз он ее посетил в том же статусе купчины, но находясь в подчинении более высокого по статусу посла Мухаммад Сали-бека в 1627 г. [13]. Во второй раз он прибывает во главе собственного торгового представительства в конце 1629 г. либо в самом начале 1630 г. (точно до дня и месяца его прибытие установить трудно). Прибыл он в Терки, где он и его люди провели около трех месяцев, прежде чем отправиться в Астрахань. В целом, как было отмечено О.М. Ястребовой и С.Е. Костиковым, сложно определить точное количество людей в представительстве, поскольку оно менялось в процессе продвижения к Москве. Именно поэтому в собственных росписях Рахмата указывается одно количество участников, а в сопроводительной документации представлены другие цифры.

Так в «росписи людем» Рахмата, направившихся с ним из Астрахани вверх по Волге, указан 21 человек [15, 
л. 41-42]. На момент прибытия с ним было 13 человек [37, p. 39]. К приезду в Казань появились еще 12 сопровождающих, часть которых составляли нанятые в Астрахани юртовские татары. В росписи указаны не только их имена, но и должности: «Хозя Мурза толмачъ», «Аким Мизан лекарь», «Юсуф казначей», «Заман бритовник», «Шахов сокольник казенной Мамедели», «Накрачей (ударяющий в накру, т.е. в бубен или литавру) [28, с. 243]. Мурат Хан, «Сурначей (от татарского зурна - труба, трубач) [27, с.50] Алибек» и «Хлебник Уста Магамет». Вероятно, не имеет смысла обозначать точное количество людей представительства, поскольку по мере продвижения к Москве Рахмат оставлял своих людей торговать в Астрахани, в Казани и в Нижнем Новгороде, где они действовали самостоятельно, но от его имени. Среди товаров, доставленных на продажу от шаха Сефи I, в основном были ткани и изредка лекарственные травы, и продукты. Роспись шахских товаров и ее перевод [15, л. 22, 23-25] имеют небольшие расхождения. Например, в оригинале открывает список «кадак фирузфурская простая - восемь тысяч» (по-видимому, имеется ввиду «киндяк» - окрашенная бумажная ткань синего или голубого цвета) и в переводе на первом месте указано «пятьдесят киндяков добрых фирисперевых» (фириспири, переспири, фереспири от персидского «фарасп» - ткани с богатым узором, которыми украшали стены в праздничные дни) [19, с. 398].

Наименования товаров, которые мы ранее переводили с персидского языка в рамках нашего проекта, уточнялись с имеющимися словарями русской лексики XI-XVII вв. Согласно предоставленной им росписи, Рахмат привез от шаха: «пятьсот дорогов кашанских» (от персидского «доройи» - полотняная ткань с по-разному окрашенными нитями основы, нитями основы нескольких цветов, или же ткань, нити которой окрашивались особым образом перед ткачеством) [20, с. 160]), пятьсот дорогов ряшских (ряшских, ряский означает произведенный в городе Рашт [25, с. 292], есть также предположение, что имеется ввиду город Ареш), тысяча дорогов гилянских, четыреста юфтей («юфть» - пара, счетная единица, употребляемая при изготовлении и продаже некоторых товаров, преимущественно выделанных из кожи, в данном случае сафьяновой, т.е. тонкая и выделанная кожа козлиная или овечья) [18, с. 286] сафьяновых, тысяча пятьсот зенденей (зендень - род шелковой материи либо бумажной ткани, изначально производимой неподалеку от Бухары и распространившейся по территории Ирана) [1, с. 47] бухарских, двадцать тювалов бумаги хлопчатой, пять тысяч ансырей (мера веса, употребляемая преимущественно для взвешивания шелка) $[18$, с. 62] шолку аливанского, восемь вьюков [18, с. 89] шолку сырцу (некрученый тонкий шелк, получаемый при размотке коконов) [21, с. 240], триста полукисей (полукисея - наиболее дешевый сорт кисеи - плотной бумажной ткани) [19, с. 398], триста выбоек (хлопчато-бумажная ткань с набивным напечатаным узором) [22, с. 179] вся- ких цветов, сто кушаков (кушак-пояс, подвязка) [22, с. 152] кашанских (произведенных в Кашане) бумажных, 30 камок (от персидского "камха», самая популярная из шелковых тканей в России XVI-XVII вв.) [5, с.50] золотных и серебряных, сто миткалей (чисто бумажная ткань) [5, c. 64], восемьсот фирисперей, семьсот борлотов (хлопчато-бумажная ткань) [9, с. 245] красных, триста кушаков харчевых (бумажные тесьмы, подвязки) [19, с. 397].

По данной росписи уже к тому времени, как Рахмат был на пути от Казани к Москве, в Терках и Астрахани было продано им: «двести фирисперей, триста борлотов красных, тысяча двести кумачей гилянских, семьсот пятьдесят бязей (плотная хлопчатобумажная ткань) [9, с. 83] лошоных, сто полукисей, десять тысяч аршин бязи, двести пятьдесят стоп (мера, равная длине ступни) [18, с. 248] бязи, пятьсот зенденей бухарских, семьсот кушаков, сто стоп выбойки». На продажу в Астрахани было оставлено: «тысяча двести кумачей гилянских, двести пятьдесят миткалей белых, двести пятьдесят стоп бязи, сто стоп выбойки всякими цветы, сто полукисей, сто стоп бязей гилянских, сто бязей меньшая руки» (имеется в виду небольшого размера) [25, с. 239].

В другой росписи [15, л. 56-59] шахских товаров, данной в Москве, указаны: «два сундука с камками и дорогами, двенадцать тай (тай, тайка, тая - кипа товара, особенно шелка, хлопка) [34, р. 88] з дорогами гилянскими, тая $з$ дорогами кошанскими, шесть коробей з дорогами гилянскими, тридцать пять тай с киндяки, тридцать тай с сафьяны, три тай з барсы, две тай кумачей, двадцать две тай с шолком цветным, пять сундуков с шолком цветным, пятьсот десять тай с шолком сырцом, две тай миткалей, две тай фирисперей, тая зенденей, тая краски крутику (название краски синего цвета, получаемой из листьев растения крутик, синельник) [24, с. 88], тая с корсаки (корсак - лисица, добыча меха которой была промыслом) [27, с. 454 ], мешок ладану, сундук с мылом, пятьдесят три мешка пшена сороцинского, мешок с перцом да анисом, мешок с ызынбилем (предположительно речь идет о плетеных корзинах и вероятно небольшого размера) [23, с. 159], тая с орешки чернильными, мешок с чилибухою (имеется в виду чилибуха или «рвотный орех»), тая да мешок с табаком, мешок иру (аир - лекарственное растение), тая попоны и с коврами цветными да в ней же табак, шесть мешков с пухом, две таи с ковры и с попонами, тая с ковры и шатрами с полатки, да две полсти больших да четыре попоны арабских, коробя с судами серебряными, сундук с судами с ценинными (вероятно имеется в виду - китайскими), сундук с перцом и с ынбирем и з гвоздик, сундук с сахаром и со ягоды розными и узды и седла, сундук с гребенем, мешок с орехи грецкими, сундук с судами всякими, шестнадцать кип (кипа как мера исчисления бумаги, точное количество стоп в кипе для древнего времени неизвестно, позже она могла включать от 10 до 16 стоп [18, с. 124] бумаги хлопчатые. 
В ней же сообщается, что в Казани оставлено на реализацию: «двадцать две переспири, сто двеннадцать ансырей шолку арясково (Ряский - из Рашта) [25 с. 292], двести шестьдесят пять кумачей, двенадцать выбоек бухарских, одиннадцать выбоек арапских, сто шестьдесят ансырей шолку пырсу (пырса, бурса или пурса - очень дорогая турецкая или персидская шелковая ткань с вытканным узором, вроде парчи) [27, с. 457], две пестреди (пестредь, пестрядь - пеньковая грубая пестрая ткань, сделанная из ниток двух цветов - крашеной основы и белого утка, или наоборот) гилянских, пять бязей толстых, пятьсот двадцать бязей лощенных, две кисеи, три пестреди бухарских, выбойка арапская, триста девяносто девять ансырей шолку гилянского, двадцать пуд бумаги хлопчатой, тридцать шесть дорог красных камки, тринадцать киндяков цветных, одиннадцать зенденей цветных, семь юфтей сафьянов красных и триста гребеней деревяных».

Оставив своих поверенных с товарами в крупных городах России, Рахмат и сам находясь на казенном обеспечении, прибыл в Москву в начале марта 1631 г. Исходя из данных официальных документов, 9 (19) Марта 1631 г. он был приглашен на официальную аудиенцию к царю Михаилу Федоровичу и его отцу Патриарху Филарету. Церемониал его приема достаточно подробно описан в статье О.М. Ястребовой и С.Е. Костикова [37], и мы не будем подробно на нем останавливаться, отметим лишь, что, действительно, обладая статусом купчины, он не обсуждал с государем и дьяками Посольского приказа вопросы политического содержания. Поскольку все тексты челобитных Рахмата, составленные на персидском, ранее были опубликованы, и в них во многом обозначены все злоключения, которые он претерпевал на своем пути, мы представим информацию из текстов тех его челобитных, которые ранее не рассматривались.

В одной из челобитных, ранее не опубликованных, Рахмат просил государя, чтобы двум его торговым людям: Менужеру (скорей всего в оригинале персидское имя - Манучехр) и Хозе Халилу (Ходжа Халил) разрешили закупить в Ярославле «тин красных («тинь»- ремень, плеть) $[26$, с. 348] и иных ярославских товаров», а также по закупке снабдить последних суднами «с чердаком» и провожатыми до Астрахани [15, л. 84]. В итоге, как оказалось, закупить предполагалось «заповедные товары» (медь, олово и свинец). О чем сразу сообщили воеводы из Ярославля на имя государя, и было начато разбирательство $[15$, л. 110]. Вторая челобитная датируется 21 марта 1631 г. и была составлена, по-видимому, на обратном пути, после того, как он был отпущен из Москвы. В ней он жаловался на то, что после него в Астрахань прибыли еще два купчины от шаха, и что им не были выданы положенные (по его пониманию) деньги на продовольствие. Рахмат просил также выдать довольствие сверх положенного, поскольку состав делегации увеличился и соответственно возросли расходы. Этот купчина своим приездом открыл последующую вереницу торговых представительств от Сефи I, изредка дополняемую приездами послов и гонцов. Он мало отличался от остальных торговых людей, прибывавших в Россию, разве что в сравнении с ними по натуре был более авантюрного склада. Подтверждением этому служит и попытка Рахмата закупить запрещенные к продаже товары, и то количество челобитных в связи с различными происшествиям, которые он подавал в Посольский приказ.

\section{ЛИТЕРАТУРА}

1. Бахмутова Е.К. Иранские элементы в деловом языке Московского государства // Ученые записки Казанского государственного педагогического института. 1940. Вып. 3. С. 40-71.

2. Броневский С.М. Исторические выписки о сношениях России с Персиею, Грузиею и вообще с горскими народами, в Кавказе обитающими, со времен Ивана Васильевича доныне. СПб.: Центр «Петербургское востоковедение», 1996. 232 с.

3. Зоннештраль-Пискорский А.А. Международные торговые договоры Персии. М.: Моск. ин-т востоковедения им. Н. Н. Нариманова при ЦИК сссР, 1931. 254 c.

4. Иванов М.С. Очерк истории Ирана. М.: Госполитиздат, 1952. 467 с.

5. Клейн В. Иноземные ткани, бытовавшие в России до XVIII в. и их терминология. М.: Издание оружейной палаты, 1925. 67 с.

6. Кораев Т.К. Московская Русь и Сафавидский Иран в Прикаспии XVI-XVII вв.: Соседство, соперничество, сосуществование // Исторический вестник. 2015. № 11 (158). C. 154-199.

7. Костиков С.Е., Ястребова 0.М. Челобитные иранского купца Хваджи Рахмата царю Михаилу Федоровичу (1613-1645) из Российского государственного архива древних актов // Письменные памятники Востока. 2019. № 37 (2). С. 122-145.

8. Куканова Н.Г. Очерки по истории русско-иранских торговых отношений в XVII - первой половине XIX в. Саранск: Морд. гос. изд-во, 1977. 286 с.

9. Мжельская 0.С. Словарь обиходного русского языка Московской Руси XVI-XVII вв. Вып.1: А-Бязь. М.: Наука, 2004. 331 с.

10. Новосельцев А.П. Русско-иранские отношения в первой половине XVII в. // Международные связи России в XVII-XVIII вв. М., 1966. С. $103-121$.

11. Павлова И.К. Хроника времен Сефевидов (Сочинение Мухаммад-Масума Исфахани «Хуласат ас-сийар»). М.: Наука, 1993. 120 с.

12. Петрушевский И.П. Народное восстание в Гиляне в 1629 г. // Ученые записки Института востоковедения АН СССР. 1951. № 3. С. $226-256$.

13. Российский государственный архив древних актов (далее - РГАДА). Ф. 77. Оп. 1. Столбцы. 1627. Д. 1. 
14. РГАДА. Ф. 77. 0п. 1. Столбцы. 1629-1632. Д. 5.

15. РГАДА. Ф. 77. 0п. 1. Столбцы. 1630. Д. 1.

16. РГАДА. Ф. 77. ОП. 1. Столбцы. 1631. Д. 1.

17. РГАДА. Ф. 77. Оп. 1. Столбцы. 1640. Д. 1.

18. Романова Г.Я. Объяснительный словарь старинных русских мер. М.: Университет Дмитрия Пожарского, 2017. 291 с.

19. Русско-индийские отношения в XVII в.: сборник документов. М.: Издательство восточной литературы, 1958. 455 с.

20. Сазонова Н.В. Мир сефевидских тканей: История, эстетика, технология, использование, каталог коллекции ГМВ. М.: Государственный музей Востока, 2004. $187 \mathrm{C}$

21. Сергеев М.Е., Архангельский Н.А. Краткий курс товароведения промышленных товаров. М.: Государственное издательство торговой литературы, 1955. 512 c.

22. Словарь русского языка XI-XVII вв. Т. 3. М.: Наука, 1976. 291с.

23. Словарь русского языка XI-XVII вв. Т. 6. М.: Наука, 1979. 363 с.

24. Словарь русского языка XI-XVII вв. Т. 8. М.: Наука, 1981.355 с.

25. Словарь русского языка XI-XVII вв. Т. 22. М.: Наука, 2004. 298 с.

26. Словарь русского языка XI-XVII вв. Т. 29. М.: Наука, 2011. 480 с.

27. Торговля с Московским государством и международное положение Средней Азии в XVI-XVII вв. Л.: Изд-во АН СССР, 1932. 504 с.

28. Шипова Е.Н. Словарь тюркизмов в русском языке. М.: Наука, 1976. 444 с.

29. Ястребова 0.М., Писчурникова Е.П., Костиков С.Е. Из истории русско-персидских языковых контактов эпохи Сефевидов. Русские заимствования в челобитных купчины Хваджи Рахмата // Ученые записки Петрозаводского государственного университета. 2019. № 4 (181). С. $48-55$.

30. Doerfer G. Türkische und Mongolische Elemente Neupersischen. Bd. III. Wiesbaden: Franz Steiner, 1967. $670 \mathrm{~s}$.

31. Foran J. The long Fall of the Safavid Dynasty: Moving beyond the Standard Views // International Journal of the Middle East Studies. Vol. 24. № 2. P. $281-304$.

32. Lockhart L. The Fall of the Safavi Dynasty and the Afghan Occupation of Persia. Cambridge: Cambridge University Press, 1958. 583 p.

33. Newman A.J. Safavid Iran. Rebirth of a Persian Empire. London: I.B. Tauris \& Co Ltd., 2009. 296 p.

34. Pohl H.D. Слова иранского происхождения в русском языке // Russian Linguistics. Vol. 2. № 2. P. 81-90.

35. Savory R. Iran under the Safavids. Cambridge: Cambridge University Press, 2007. 277 p.

36. Shorokhov V.A., Slesarev T.A. Archive Files on the Şahin Geray's Contribution to the Russo-Persian Relations // Vestnik of Saint Petersburg University. History. 2020. Vol. 65. Issue 2. P. 618-632.

37. Yastrebova 0.M., Kostikov S.E. Bondsman of Two Monarchs: Documents on the Persian Kirakyaraq Khwaja Rahmat's Mission to Moscow in 1629-1631 // Manuscripta Orientalia. International Journal for Oriental Manuscript Research. 2019. Vol. 25. № 2. P. 37-46.

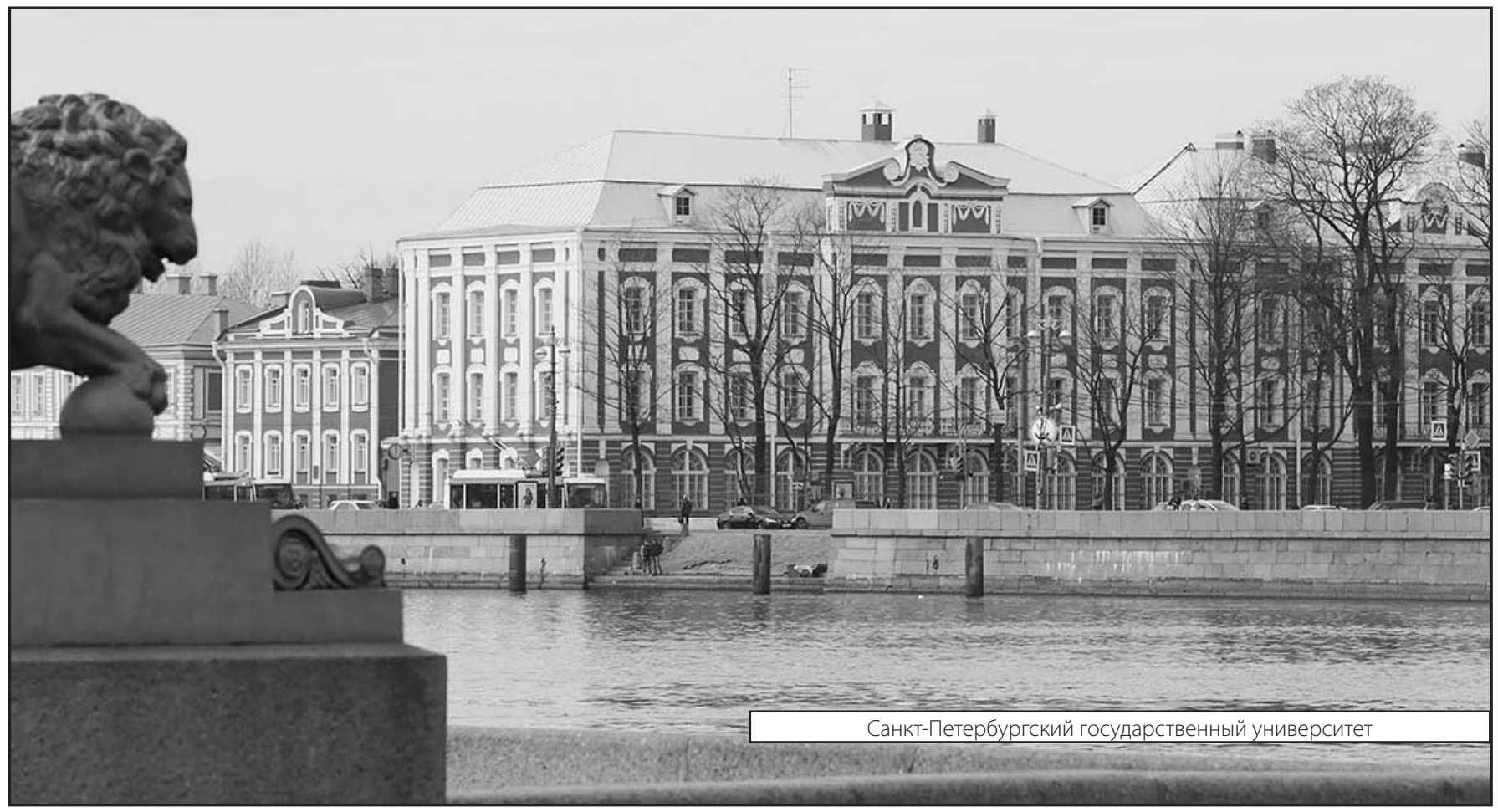

